\title{
LABOUR AND EMPLOYMENT CREATION WITH AFRICAN RESOURCE DEVELOPIMENT
}

\author{
Franklyn Lisk*
}

\begin{abstract}
Natural resources are an assured source of government revenue, but this does not always translate into more jobs, better productivity or an increased demand for that country. Traditionally, the role of government in a resource-rich country has always been to act in the best interests of its citizens. In the case of natural resource-rich nations, this role also includes ensuring that jobs in the extractive sector are safe - both in the physical and financial sense. In such competitive environments, the private sector also has a fiduciary responsibility to ensure that all employees are fairly treated. However, it is evident that almost all African nations that are rich in resources are affected by lack of human development. This article examines the current state of affairs in the resource-rich African nations and their impact on human development. It focuses on how these resource-dependent economies are experiencing economic growth and why this growth does not directly translate into higher and better employment for the local populations. The article examines growth and human development from the perspectives of both the private- and public-sector actors. It recommends that private actors should have a complementary approach, through foreign direct investors or other modes, to the long-term policies and plans set out by the state. This approach would allow for successful intersectoral linkages and community development through higher job creation. It argues that the state is responsible for managing these natural resources and highlights the role of governance in this management. Governance issues, challenges, such as developmental gains, job creation, transparency and accountability are all addressed in the article. Finally, the article strongly recommends developing both human and institutional capital and regulating production.
\end{abstract}

Keywords: Resource development, resource curse, Africa, governance, management.

DOI: https://dx.doi.org/10.4314/jsdlp.v8i1.12

* Professorial Research Fellow, Centre for the Study of Globalization and Regionalization (CSGR), University of Warwick, UK. Email: f.lisk@warwick.ac.uk 


\section{INTRODUCTION: ISSUES IN AFRICA'S NATURAL RESOURCE DEVELOPIMENT}

Africa's abundant reserves of natural resources ${ }^{1}$ account for a significant share of exports in more than half of the continent's 54 countries. Over the past decade, both the volume and value of Africa's minerals, metals and oil have increased dramatically and the value of certain minerals more than tripled until the end of the commodity super cycle in 2014/ 2015. Natural resource extraction in Africa has attracted huge capital investments in the post-independence era, ${ }^{2}$ and in many countries the extractive sector has been the dominant driver of GDP growth and wage employment opportunities in many countries for decades. The vast resource wealth of Africa holds great potential for investment in physical and human development and the creation of additional productive and remunerative jobs to meet the employment needs of the teeming millions of young Africans who enter the continents' labour force annually.

Looking ahead, resource wealth also provides an unprecedented opportunity for African countries to make a breakthrough ${ }^{3}$ in transforming and diversifying their economies away from primary production and investing in industrial development as the foundation for sustainable growth and significant reduction in poverty. So far, harnessing Africa's natural resource development and translating resource wealth into inclusive economic growth and long-term sustainable development has been problematic, leading to the rather paradoxical question: How can a continent be so rich in natural resources, including some of the most sought-after minerals in the world and yet be so poor in human and physical development?

Despite decades of benefiting from enormous resource wealth, several mineral-rich African countries are still terribly short of vital physical infrastructure and quality human capital required for transforming their economies and improving living standards. Many of

1 Africa is endowed with some of the world's largest mineral reserves, including three-quarters of the world's platinum supply, half of its diamonds and chromium, up to one-fifth of gold and uranium supplies, vast deposits of coal, cobalt and iron-ore and huge reserves of oil and gas; the continent also has more than half of the world's uncultivated land suitable for farming and a wide variety of agroecological zones, including thousands of miles of fish-rich coastline.

2 Available from: <www.afdb.org > accessed 17 June 2016.

3 Available from: <www.africaprogresspanel.org > accessed 17 June 2016. 
Africa's richest resource countries rank amongst the lowest on the UNDP Human Development Index (HDI). ${ }^{4}$ For instance, oil-rich Angola and Equatorial Guinea are among countries with the highest maternal and infant mortality rates in the world; the Democratic Republic of Congo (DRC), which probably has the continent's richest deposits of minerals, and Niger, the largest exporter of uranium, both lurk at the bottom of the aggregate HDI. The focus of this paper concerns the failure of mineralrich countries to use resource wealth to create sufficient productive and remunerative jobs. This calls for an examination of the relationship between natural resource management and employment generation in the context of national development planning strategies, policies and programmes.

The article ascribes significant macroeconomic policy and regulatory roles to the state with respect to leveraging Africa's extractive sector for economic development and transformation linked to the creation of more productive and better jobs. In terms of development strategy, African governments should use their resource wealth to foster inclusive and diversified economic growth and promote industrialization, including agribusiness, while also addressing skills mismatch in the labour market which acts as a constraint on access to current and future formal sector employment opportunities. From a human security perspective, and to eliminate threats to the well-being of the individual, African governments should ensure that the working conditions and environment in the extractive sector are safe and the pay adequately remunerative.

The article equally recognizes the complementary role of the private sector in supporting the central role of the state to promote inclusive development and create quality jobs from natural resources extraction. This supporting role of local and foreign direct investors in the extractive sector in Africa is absolutely essential for successful development and extending the benefits of resource-based growth into job-creation in other parts of the economy through inter-sectoral linkages. As we have seen so far, natural resources are an assured source of government revenue but not a particularly immense or important source of jobs, productivity, or demand. The key challenge will be to work out how resource-rich economies can move towards a job-rich growth pattern,

4 Available from: <www. hdr.undp.org > accessed 17 June 2016. 
including in particular how the state and the private investors in the extractive sector can be mutually supportive.

The central role of the state in managing natural resources and regulating extraction in Africa brings into focus the troubling question of governance. The debate on governance requirements for translating resource wealth into development gains, including opportunities for creating more decent jobs, tends to concentrate on governance issues of transparency and accountability. The article draws attention to the importance of building up human and institutional capacities within African countries for effective contract negotiation and regulation of production in the extractive sector in an efficient and revenuemaximizing manner.

The article is structured as follows. Following this introduction, the first section presents an overview of labour market and employment challenges in Africa's natural resource development, reiterating the fact that despite the continent's endowment of abundant natural resources it has made little impact on the creation of more and better jobs. Also, despite impressive resource-driven economic growth performance over the past decade, levels of unemployment and underemployment across the region have been persistently high and rising, especially among young men and women.

As argued later, the general lack of formal employment opportunities for the youths, underpinned by exclusion from purposeful employmentoriented education and training systems, suggests that the chances for Africa to benefit from a demographic dividend, which contributed to rapid structural transformation and unprecedented growth rates with massive job creation opportunities and reductions in poverty in East Asia, are slipping away quickly. Against the background of challenges the labour market and employment landscape, the second section of the article explores governance and capacity concerns in natural resource management in Africa, addressing accountability and partnership obligation as well as competency in international contract negotiation and resource management.

This is followed by a section which discusses how Africa can leverage its rich natural resources for structural transformation towards more productive activities and better jobs to achieve inclusive economic growth and sustainable development - already a focus policy and action at the continental level (AU, 2011;UNECA, 2011; UNECA, 2012; Ncube, 2012a;Lopes, 2014; AfDB, 2015). In this regard, reference is made to 
the Africa Mining Vision, ${ }^{5}$ which aims to successfully harness the full potential of Africa's minerals for development in relation to natural resource development and employment gains (AU, 2009).

In the final section, by way of conclusion and recommendations, the article calls for a rethink of the value of the extractive sector for national development, and argues that African countries should cease from viewing mining essentially as rent-seeking but an opportunity to buttress broad-based structural transformation. This implies the need for a policy-relevant approach to mining and oil and gas exploration that aligns resource development with the wider development agenda and objectives for economic transformation and social and environmental sustainability. This can be done by: enabling economic linkages between the extractive sector and the economy as a whole; optimizing revenues from natural resources and investing them strategically to promote economic diversification and increase productivity; and establishing specific conditions required for natural resources to thrive and drive desirable structural transformation. ${ }^{6}$

\section{LABOUR MARKET AND EMPLOYMENT CHALLENGES IN AFRICAN RESOURCE DEVELOPIMENT}

Young people aged between 15 and 25 years (i.e. "the youth", as defined by the United Nations) represent more than 60 per cent of Africa's total population and account for 45 per cent of the continent's total labour force (ILO, 2015).The working-age population (15-64 years) in Africa increased from under 100 million in 1970 to over 600 million in 2014. Hence, Africa's rapidly growing population is more youthful compared with other developing regions, with three-quarters of the total population or about 750 million under age $30 .{ }^{7}$ Owing to

5 The Africa Mining Vision which was adopted in 2009 by African leaders at the AU advocates shift in policies away from an ingrained focus on extracting minerals to generate revenue for governments to that of underpinning broadbased sustainable growth and transformative and inclusive socio-economic development, as relevant for job creation and poverty reduction. See African Union Commission (AUC), 2011.

6 As advocated in African Union. 2009. Africa Mining Vision; African Union (2014), Agenda 2063 Vision and Priorities; and UNECA (2015), Industrialization through trade. Economic Report on Africa 2015.

7 Available from: <www.ilo.org > accessed 17 June 2016. 
the high fertility rate underlying the continent's demographic structure and momentum, it is projected that by 2020 three out of every four Africans will be less than 20 years. ${ }^{8}$ The continent's 250 million youth population is set to reach one billion by 2050, representing more than half of the world's youth population. Africa's youth bulge represents a major development challenge in terms of finding gainful employment for the estimated 10-12 million added ${ }^{9}$ to the workforce annually. The employment outlook for youth entering the labour market in African countries does not look promising.

Job opportunities have not kept pace with rapid population growth in the continent, even in the context of recent resource-driven high growth performances in many countries. In addition, there is the persistent problem of long-term unemployment spells affecting millions of Africa's youth already in the labour market as well as those forced to take up less than ideal (low-paying) jobs in the informal economy. Many young people have poor access to basic education (functional literacy and numeracy) and, with little or no employable skills, they are largely excluded from productive economic and social life. Furthermore, even those who have gone through education and training often have inappropriate (paper) qualifications and lack practical experience that limit their employability training in relation to current demand in the labour market, resulting in millions of educated unemployed and underemployed youth. The stagnation in formal sector wage employment growth in many African countries, despite recent high resource-based economic growth, means that tens of millions of youth are engaged in low-pay and low-productivity work in the informal sector.

While expected decline in fertility and mortality rates in the coming two decades offers an opportunity for Africa to reap a demographic dividend and foster job-creating economic growth, there are equally concerns about the prospect of capturing this dividend judging from existing flawed labour market conditions and poor human resource development and utilization mentioned above. Africa's strong resourcedriven economic growth of the last decade has not translated into enough formal employment opportunities, particularly for new labour market entrants. Production activities in the dominant extractive sector

8 Available from: <www.afdb.org > accessed 17 June 2016.

9 Available from: <www.iyfnet.org > accessed 17 June 2016. 
in most African countries are largely capital-intensive and with little inter-sectoral linkages which severely limit employment creation potential. ${ }^{10}$

The employment challenge in Africa is primarily structural and therefore needs structural solutions. In addition to the predominance of capital-intensive growth patterns in Africa, labour markets throughout the continent are in disarray and characterized by skills mismatch founded in limited relevance of education and training to current and future job opportunities. The outlook is further worsened by low productivity, precarious jobs and truncated earnings in the informal sector where the majority of the workforce eke out a living, and lack of social protection. Employment vulnerability in Africa is the highest of all the developing regions.

The combination of these two limiting factors: (1) an economic growth deriving mainly from capital-intensive extractive production activities, and (2) many young people leaving the education system without basic literacy and numeracy skills or with qualifications that do not match the needs of the labour market, underline labour market and employment challenges in African natural resource development. ${ }^{11}$ The solution to this dilemma in natural resource development should, therefore, revolve around strategies and policies to attract investments which provide new opportunities for job creation through optimizing linkages and value-additions within and outside the extractive sector in a sequenced and phased manner, in the context of efforts toward industrialization at the national and regional levels, and alongside labour market measures to provide more appropriate education and targeted skills development.

The role of the state is critical in providing a favourable macroeconomic and business environment and an appropriate regulatory framework for integrating the extractive sector with the rest of the economy and in adopting comprehensive economic development policies, notably with respect to education and skills formation and industrialization (Campbell, 2004; Campbell, 2009; Campbell, 2010; Gajigo et al, 2012b; APP, 2013). The creation of jobs, and better quality jobs for that matter, in the extractive sector cannot be viewed as an independent policy, but must be an overarching objective integrated

10 Available from: <www. www.un.org > accessed 17 June 2016.

11 Available from: <www.afdb.org > accessed 17 June 2016. 
in a comprehensive package of public policy actions in partnership with private and social actors. Successful resource-based industrialization will, therefore, also depend on the extent to and how governments provide opportunity and scope for private-led initiative and collaborative partnerships within the regulatory framework for optimizing different forms of linkages within and beyond the extractive sector.

Foreign investors operating in the extractive sector in Africa must become more socially responsible and morally accountable on matters pertaining to the payment of taxes and royalties, based on appropriate legislation designed to ensure that such investors and multinational enterprises contribute to and support national and local development (Collier, 2012; Gajigo et al, 2012a; APP, 2013; Besada and Martin, 2014; $A U, 2015)$. International actors, from businesses to financial institutions and donors, also have a role to play in terms of contributing to improving labour and employment conditions in the extractive sector in Africa through standard setting, the design of their interventions and monitoring and evaluation (ECOSOC, 2009; US Government, 2010; IMF, 2012; OECD, 2014; World Bank, 2015; Besada, Lisk and Martin, 2015).

The pace of job creation from natural resource development and allied economic activities must accelerate to keep up with the growth of Africa's labour force each year. There are pressures for quality education that creates productive and competitive skills, workforce skill upgrading and employment opportunities targeted atthe large cohorts of youths in the labour market. While national policy makers across the continent and their international development partners are beginning to devise solutions to curb youth employment crisis, success or failure will be determined by how effectively and quickly young people are given the space and socio-economic opportunity for them to develop and make use of their talents, including support for selfemployment and entrepreneurship in the extractive and allied sectors (Jonsson and Bryceson, 2009; Bryceson and Jonsson, 2010; De Backer, 2012; Global Witness, 2012; Bulakali, 2014).

The transition from schooling to employment in resource-rich economies must be based on education and training systems that instil practical (extractive and allied) industry-oriented skills amenable to both large and small firms in the sector, including requirements for self-employment (Oyejide and Adewuyi, 2011; Mbayi, 2011; ILO, 2015). Technical and vocational skills development can be an important tool for enhancing access to jobs in the extractive sector, especially when 
undertaken in cooperation with industry and against the background of the evaluation of relevant labour-market information.

\section{GOVERNANCE ISSUES IN AFRICAN RESOURCE DEVELOPIMENT}

New discoveries of minerals and oil and gas across Africa underscore the potential of Africa's natural resources to foster long-term growth, human development and create new opportunities for productive employment in the post-2015 era. Yet on the basis of ample, reliable evidence, the potential of the extractive sector to serve as a catalyst for long-term, competitive, inclusive and sustainable development has long been stifled by political and economic governance challenges confronting resource-rich countries in the continent (Collier and Venables, 2011; Kaufmann, 2012; Ross, 2012; APP, 2013; AU, 2015; Burgis,2015; Roberts, 2015; Stevens et al, 2015; UNECA, 2015). Governance challenges as such could undermine prospects to link resource wealth from the extractive sector with desirable development objectives such as inclusive growth and poverty reduction. Hence, there is a growing consensus that priority should be given in natural resource management in Africa to the need for transparency, legitimacy and accountability, and the existence of appropriate institutional and consultative arrangements involving key stakeholders - governments, the private sector, civil society organizations and local communities for better regulation and greater prosperity (Campbell, 2004; Campbell 2009; Hilson and Maconachie, 2009; UNECA, 2009; Le Billon, 2011; Transparency International and Revenue Watch, 2011; Collier, 2012; Ernst and Young, 2012; APP, 2013; Besada and Martin, 2014).

New revenues generated by the extractive industry resources - if properly harnessed and effectively managed - can yield innovative and mutually beneficial public-private collaborative solutions for resourcebased development and structural transformation with significant employment gains across sectors in mineral-rich African countries. The extent to which positive local development and employment benefits of resource extraction are attained will be influenced by the effectiveness of measures to detect and avoid corruption, promote shared value, and enhance judicious revenue spending and investment - in other words, the quality of governance over the activities of the key stakeholders in the extractive sector (UNCTAD, 2013; Holland, 2014; APP, 2013; OECD, 2014). 
It is important to recognize and address governance challenges on the basis of global protocols for transparency and responsibility such as the Extractive Industries Transparency Initiative (EITI) ${ }^{12}$ and the International Council on Mining and Metals (ICMM) or international guidelines offered by recommended and the Natural Resource Charter. It is further essential to realize that adequate and effective governance will also depend on national capacity to negotiate (contracts and deals), legislate and regulate, on prevailing local practices pertaining to accountability measures, revenue collection and sharing, domestic employment and investment requirements, and on social and environmental safeguards. Implementation of governance requirements in practice calls for the combined efforts and shared responsibility between African governments and their regional and international development partners, such as the AfDB and the World Bank, and foreign companies investing in the extractive sector, and enhance regional cooperation among African governments themselves (AU, 2009; McKinsey, 2010; AU, 2011; AfDB, 2012; Tedom and Noah, 2014).

Understanding the governance of natural resources in Africa has become of greater importance than ever before. This follows the changing global order with the rise of emerging economies and their increased trade with, and investment, in Africa; the impact of climate change on energy and industrial development; the effect of the global (financial, food and energy) crises on Africa; as well as the continent's quest for regional integration. The African Mining Vision (AMV), ratified by African Union Heads of State in 2009 (AU, 2009), and its accompanying Action Plan (AU, 2011), represent potentially important steps toward beneficial and accountable natural resource exploitation in the continent. These can transform Africa's enormous economic potential and resource wealth into tangible benefits in terms human and physical development, economic stability, peace and security with significant employment gains.

The 2012 African Development Forum (ADF-VIII) - a combined UNECA, AU Commission and AfDB event - was organized under the theme "Governing and Harnessing Natural Resources for Africa's

12 The EITI grew out of the "Publish What You Pay" campaign, spearheaded by NGOs, which called on multinational companies in the extractive sectors to report all payments to governments and public officials in countries where they operated. 
Development", which underscores the importance of natural resource governance in the economic and social transformation processes in Africa to foster inclusive growth, employment creation and poverty reduction (UNECA, 2012). Similarly, the 2013 Africa Progress Report by the Kofi Annan led Geneva-based think tank, Africa Progress Panel, entitled "Equity in Extractives: Stewarding Africa's natural resources for all" stressed that transparency, effective regulation and good corporate governance can unlock the potential of extractive industries to operate as an important source of employment and income for a vulnerable workforce in Africa (APP, 2013).

Over the past two decades, it has variously been claimed that Africa can benefit from its resource wealth only if the resource curse is avoided and appropriate institutions for the governance of natural resources are put in place (for example World Bank, 1992; Campbell, 2004; Ross, 2012; Roberts, 2015; Stevens et al, 2015). Nobel prize-winning economist Joseph Stiglitz similarly observed in a commentary on the subject in The Economist (11 February 2012) that Africa's natural resources can be a blessing and not a curse if they are managed effectively. There is little doubt that with good governance, resource wealth can go a long way towards solving the problem of scarcity of domestic capital to finance labour-intensive infrastructure and development projects and programmes and to invest in education and training for appropriate skills formation. This removes the perennial constraint on government budgets to fund physical and human development in resource-rich African countries. The then Chief Economist of the AfDB estimated that Africa's natural resources and extractive industries will contribute over US $\$ 30$ billion per annum in government revenues in the next 20 years (Ncube, 2012b).

\section{LEVERAGING AFRICA'S NATURAL RESOURCE EXTRACTION FOR ECONOMIC TRANSFORMATION AND JOB CREATION}

Despite having a long history of natural resource exploitation, Africa remains the least explored geological region in the world, which means that the full extent and value of the continent's mineral, oil and gas resources is unknown. It has been estimated that Africa's miningsector today accounts for just 10 per cent of the total global mineral production, butwith four-fifths of the world's total future portfolio of mining projects based on four key minerals - iron ore, cooper, gold and nickel 
- which are already found in abundant quantities in Africa. The continent has been identified as the likely next future frontier for extractives (Mckinsey, 2010 and 2013; Ernst \& Young, 2012; UNCTAD, 2013; Lopes, 2014; Ncube, 2012b). Recent discoveries of these important key minerals as well as new rare and strategic minerals across Africa reinforce the view that the extractive sector has the potential to act as a game changer in human and physical development agendas. However, it is important to understand the challenges implicit in efforts to leverage Africa's extractive sector for economic development and transformation.

Poor development and employment creation performance of most mineral-rich African countries so far can be traced to differing factors. The extractive industries in most cases are heavily concentrated on upstream extraction and exports of raw primary products, with hardly any value-addition processing activities taking place locally; in addition, this upstream segment of the global extractive industry value chain is often an enclave having few links with the local economy. These peculiar characteristics of the natural resource development in Africa means that opportunities for employment and income generation are missed because of weak integration of the dominant extractive sector with the rest of the economy; the drawback on job creation is further compounded by the fact that production in the extractive sector tends to be mechanized and highly capital-intensive. Furthermore, the export of natural resources in raw unprocessed versions exposes African economies to price volatility in global commodity markets and to revenue fluctuations which in turn constrain investment in employmentgenerating activities.

Outlined in the previous section, poor governance and weak legal and regulatory frameworks underline high incidences of price fixing, tax avoidance and illicit financial flows which deprive African governments of huge financial resources that could have been used to boost human development and create additional productive employment opportunities (Le Billon, 2011; Ross, 2012; Burgis, 2015; UNECA, 2015). All of these structural factors, coupled with the fact that extractive resources tend to be exhaustible and non-renewable, make leveraging natural resource extraction for sustainable development in African countries particularly challenging.

Nevertheless, using Africa's extractive resources to propel modernization and promote sustained economic growth and development has long been recognized by Africa's leaders and policymakers at national and regional levels, dating back to the Organization 
of African Unity (OAU) Lagos Plan of Action for the Economic Development of Africa, 1980 to 2000 and more recently the landmark Africa Mining Vision endorsed by African Union (AU) heads of states in 2009 in Addis Ababa(AU, 2009). Hence, there seems to be no lack of direction for the formulation of credible mineral policy reforms driven and led by Africans. The main challenge lies in translating declarations of good intention into commitment and implementable actions with successful human and physical development outcomes. This leads us to focus on a number of conditions or requirements for transiting from statements of intent into commitment and result-oriented action in an evolving structural transformation development policy context. First, there is a need for transparent, equitable and optimal exploitation of natural resources to underpin resource-based development. Second, value addition through local processing of extractive commodities should be given high priority in investments in the sector as a means of building domestic human, financial and institutional capital that can outlast exhaustible extractive resources. Third, knowledge and institutional capacity are required for negotiating better contracts and deals and to review and question previous ones. This would ensure that they are fair in terms of tax revenues and royalties and environmental considerations. Fourth, there is an urgent need for improved legal and regulatory frameworks that will provide greater fiscal space and fair and responsive taxation to allow African countries to optimize accompanying financial benefits for physical and human development (IMF, 2012; Besada and Martin, 2014; Besada, Lisk and Martin, 2015).

Encouragingly, there are indications of determination by African leadership to give operational significance to the African Mining Vision and its "Action Plan" such as through the establishment of an African Minerals Development Centre (AMDC). The AMDC has been set up to improve the effectiveness in policy/programme formulation, planning and implementation and aimed at increasing the economic and social linkages and impacts of investments in the extractive sector. The main objective of the AMDC is to ensure that national interests and concerns in the extractive sector are properly articulated and that African countries obtain better deals from the sector for the benefit of the state and all citizens.

At least seven African countries have renegotiated existing contracts or embarked on mining contract reviews, aimed at increased taxes and royalties, export levies on raw materials, and windfall tax for exceptional profits. These include mining investments in uranium in 
Niger, iron ore in Guinea, copper in Zambia, gold in Mali, and oil in South Sudan (Lopes, 2014). New mining codes in countries such as Namibia, Mozambique, Zambia and the DRC recognize a role for indigenous operators in the extractive sector, which can have potentially favourable labour and employment implications through measures aimed at improving the viability of small-scale and more labourintensive mining operations (Holland, 2014; Bulakali, 2014; Global Witness, 2012; Byceson and Jonsson, 2010). More attention is also given in these new codes to contractual transparency and financial, social and environmental accountability by large foreign investors and direct contribution to local economic development of mining areas. In addition, there are increased direct and indirect income earning opportunities for the local population, including possibilities for subcontracting and local procurement (Mbayi, 2011; Oyejide and Adewuyi, 2011; World Bank, 2012; Besada and Martin, 2014;).

Requirements of compliance with international standards of governance through, for example, the Extractive Industries Transparency Initiative (EITI), the US Dodd-Frank Act (US Government, 2010) and similar EU legislation are contributing towards the institutionalization of guidelines for improved transparency and accountability in contract negotiations and, hence, prospect for the better management in African natural resource development. Fair mining concession and taxation, value-addition through local processing before export and the development of stronger linkages between the extractive and other sectors of the national economy, alongside innovative and transformative partnerships, are envisaged under the African Mining Vision.

Already, there is evidence that these measures, if implemented effectively and in good time, have the potential to yield significant employment and development outcomes (Mbayi, 2011; Gajigo et al, 2012b; APP, 2013). The decision by De Beers, following persuasion by the Government of Botswana, to move its entire sight-holder sales facility - where the company's major customers come to inspect and buy boxes of rough diamonds 10 times a year - to Gaborone, Botswana's capital, from London in 2013 has resulted in a number of the sightholders setting up their own diamond cutting and polishing factories in Botswana. ${ }^{13}$ These are located within the high-security Diamond

13 Available from: <oro.open.ac.uk> (17 June 2016). 
Technology Park established by the government to promote a local diamond processing industry. The marketing of raw stones and the carrying out of cutting and polishing operations locally in Botswana's diamond mining industry have had significant direct and indirect employment impact. It is estimated that within a year over 700 new jobs, including high quality employment, have been created within the industry and in other productive sectors, including the hotel and hospitality trade, as well as improving business prospects for local entrepreneurs. Furthermore, these positive developments within the Botswana diamond industry have exerted a big strategic push on the industry in terms of integrating and moving the country's production higher in the industry global value chain.

The Botswana example is instructive for resource-rich economies across Africa, as it indicates that with the right conditions - good governance in natural resource management and a focused industrial strategy - it is possible to create and promote employment. It is also an example in generating backward and forward linkages within the extractive sector, as well as boosting productive synergies with other economic sectors, which in effect contributes to the disenclavement of the extractive sector.

Creating more and better jobs from Africa's natural resource development is indeed urgent and pressing in the light of the continent's twin development challenges of high and rising unemployment and underemployment levels alongside persistent and widespread poverty. Therefore, governments must have a strong interest and commitment through policies and regulations to use financial resources from the extractive sector to promote human and physical development and, more specifically, create productive employment opportunities as a most important pathway out of poverty. In this regard, past experience has shown that attention has to be paid to both the quantity and quality of jobs that come from large-scale investments in the extractive sector: good jobs that offer fair pay to locals, that have good working conditions, that provide opportunities for local workers to advance, and jobs that do not discriminate against nationals vis-á-vis foreign workers or against women and youths.

As observed, particular attention should be given within the extractive sector to opportunities for locally-based small- and mediumsized enterprises (SMEs) to participate in mining operations as a way of boosting employment creation and sustaining livelihoods especially in the rural areas. This implies putting in place policies to facilitate the 
participation of local investors, including chiefly access to finance and technology, as well as measures designed to encourage and/or require foreign investors in the extractive sector to establish meaningful linkages with SMEs in extractive and other sectors of the economy (Bulakai, 2014; Byceson and Jonsson, 2010; Oyejide and Adewuyi, 2011; Morris et al, 2011).

\section{CONCLUSION AND RECOMMENDATIONS}

Globally, the scramble for access to Africa's natural resource endowments has intensified since the start of the new millennium. This provides a historic opportunity for Africa to harness and utilize its resource wealth to stimulate and fuel inclusive economic growth and sustainable development with significant job creation benefit (Gupta et al, 2009; Prichard, 2009; Pedro, 2012; UNECA, 2012; UNECA 2013; World Bank, 2015).This opportunity can be seized through interventions designed to have positive impact on the continent's development agenda. Some means include better governance, greater policy space and coherence on macroeconomic and labour market issues, and improved public policy capacity backed by efficient institutions. Innovative approaches to resource management, investment and development partnership are needed to support necessary structural transformation that will substantially increase the employment content of high resource-based growth in Africa (UNECA, 2012; Besada, Lisk and martin, 2015; AfDB, 2015).

Structural transformation is indeed crucial to provide resource-rich (and other) countries in Africa with a solid base to achieve and sustain key development objectives including, not least of all, job creation and poverty reduction. In this regard, public policies for natural resource development must be: (i) Consistent with economic development and transformation objectives and priorities; (ii) Properly sequenced to reflect development needs and political commitments that will contribute to innovation and transformation in a rational and practical manner and on a sustainable basis; and (iii) Cognisant of concurrent policies developed at regional and continental levels, particularly those embodied in relevant broader frameworks such as the African Mining Vision (AMV), the Accelerated Industrial Development of Africa (AIDA), the Programme for Infrastructure Development of Africa (PIDA) and the Comprehensive Africa Agriculture Development Programme (CAADP). 
The adaptation of a transformative framework to natural resource development in Africa would imply that more attention should be given to the extraction of minerals and style of resource wealth management that enhance much-needed economic diversification and infrastructural development. According to this approach, natural resource development in Africa should prioritize the link between the extractive sector with agriculture, which is the most important sector in terms of employment and livelihood in most African countries. This implies focusing on minerals and raw materials such as phosphate and limestone that can be used for local production of fertilizer for crops and cement needed for construction of physical infrastructure in rural areas that would boost agribusiness, promote industrialization and improve global competitiveness (FAO, 2004; Wanzala and Groot, 2013; Ecobank, 2014).

This transformative approach to extraction challenges the current orthodoxy and patterns of resource-led development which frames Africa's minerals essentially as raw materials for export and regards mining as a rent-seeking activity; it presents the extractive sector as an opportunity to attain broad-based structural transformation, based on stronger inter-sectoral linkages, greater value addition and wealth retention within local economies and with more positive and inclusive development results. This seems to be an approach that has greater potential for optimizing employment-oriented development benefits from Africa's natural resources and the extractive sector.

\section{REFERENCES}

AfDB. "Mining Industry Prospects In Africa".(Tunis, 2012)<http:// www.afdb.org/fileadmin/uploads/afdb/Documents/Publications/ Annual_Report_2012.pdf> accessed 14 January 2016.

AfDB. Delivering on the promise: Leveraging natural resources to accelerate human development in Africa(Abidjan, 2015).

Africa Progress Panel (APP). "Equity in Extractives: Stewarding Africa's Natural Resources for All, Africa Progress Report" (Geneva, 2013) < http:// www.africaprogresspanel.org/wp-content/uploads/2013/08/ 2013_APR_Equity_in_Extractives_25062013_ENG_HR.pdf $>$ accessed 14 January 2016.

African Union (AU). Africa Mining Vision, AU Commission (Addis Ababa, 2009).

AU. Track it! Stop it! Get it! : Report of the High-level Panel on Illicit Financial Flows, AU Commission and UNECA (Addis Ababa, 2015) 
$<$ www.thabombekifoundation.org.za/.../IFF_Main $\% 20$ Report_ENGLISH > accessed 14 January 2016.

AU. Building a Sustainable Future for Africa's Extractive Industry: From Vision to Action. Action Plan for Implementing the AMV.AU Commission (Addis Ababa, 2011).

Besada, H. and Martin, P. "Mining Codes In Africa: Emergence of a 'Fourth Generation"', (London: Cambridge Review of International Affairs Journal, 2014) No. 2, vol. 28,263-282<http://dx.doi.org/10.1080/09557571. 2013.840823> accessed 14 January 2016.

Bulakali, Z. "Legitimacy of Small-Scale and Artisanal Mining in Democratic Republic of Congo: The Case of Kivu" (GREATS Insights, 2014) No 7, vol.3 < http://ecdpm.org/great-insights/extractive-sector-africanperspectives/> accessed 14 January 2016.

Burgis, T. The Looting Machine: Warlords, Oligarchs, Corporations, Smugglers and the Theft of Africa's Wealth (Public Affairs: New York, 2015).

Bryceson, D. F. and Jønsson. J. B. "Gold Digging Careers in Rural East Africa: Small-Scale Miners' Livelihood Choices". (World Development, 2010) No 3, vol. 38, 379-392. doi:10.1016/j.worlddev.2009.09.003; accessed 14 January 2016.

Besada, H., Lisk, F. and Martin, P. "Regulating Extraction in Africa: Towards a Framework for Accountability in the Global South", Governance in Africa (92015) No. 1, Vol. 2, 1-12.

Campbell, B. Mining in Africa: Regulation and Development (Pluto Press: New York, 2009).

Campbell, B. "Regulating Mining in Africa: For Whose Benefit?"Discussion Paper(Nordic Africa Institute: Uppsala 2004) No 26. < http:// www.ieim.uqam.ca/IMG/pdf/Manuscrit-Eng-2004.pdf $>$ accessed 14 January 2016.

Campbell, B. "Revisiting the Reform Process of African Mining Regimes", Canadian Journal of Development Studies (2010) Vol. 30: 1-2, 197-217. <http://www.nsi-ins.ca/wp-content/uploads/2013/03/Mining-Codes-inAfrica-Report-Hany.pdf > accessed 14 January 2016.

Collier, P. The Plundered Earth: Why We Must - And How We Can - Manage Nature for Global Prosperity (Oxford University Press: New York, 2011).

Collier, Paul. 2012, "Managing Natural Resources To Ensure Prosperity in Africa". Lecture notes (UONGOZI Institute, Dar es Salaam: Tanzania, 2012).

Collier, P. and Venables, A. Plundered Nations? Successes and Failures in Natural Resource Extraction (Palgrave Macmillan: New York, 2011).

De Backer, S. "Mining Investment and Financing in Africa: Recent Trend and Key Challenges", Africa's Mining Industry: The Perceptions and Reality (Toronto, 2012).<http://www.mineafrica.com/documents/2\%20\%20Steve\%20De\%20Backer.pdf > accessed 14 January 2016.

Ernst and Young. "Global Oil and Gas Reserves Study" (2012).<http:// www.ey.com/Publication/vwLUAssets/Global_oil_and_gas_reserves_ 
study/\$FILE/Global_oil_and_gas_reserves_study.pdf $>$ accessed 14 January 2016.

Gajigo, O. E. Mutambatsere and Ndiaye, G., "Fairer Mining Concessions in Africa: How Can This Be Achieved?"Journal of Africa Economic Brief (AfDB, 2012a), No. 6, Vol. 3. <www.afdb.org > accessed 16 January 2016.

Gajigo, O. E., Mutambatsere and Ndiaye, G. "Mining Royalty Reform Need Not Deter Investors, This is Africa" (Financial Times: London, 2012b).

Global Witness. "Artisanal mining communities in eastern DRC: Seven baseline studies in the Kivus" (2012). < https://www.globalwitness.org/sites/ default/files/summary_of_baseline_studies_global_witness.pdf $>$ accessed 16 January 2016.

Gupta, S. F., Barnhorst and Thornton, J. 2009, "Natural Resource Endowments and the Domestic Revenue Efforts" European Journal of Political Economy (2009) Vol 25 (4), 439-446.

Hilson, G. and Maconachie, R. "Good Governance and the Extractive Industries in Sub-Saharan Africa", Mineral Processing and Extractive Metallurgical Review' (2009) No 1, Vol. 30, 52-100. <http://www.tandfonline.com/ doi/abs/10.1080/08827500802045511> accessed 16 January 2016.

Holland, N. "Gold Mining and Shared Value: Contributing to Development and Communities"(GREAT Insights, 2014), No. 7, Vol. 3.

International Labour Office (ILO). "Global Employment Trend for Youth 2015: Scaling up Investments in Decent Jobs for Youth" (Geneva, 2015).

International Monetary Fund (IMF). "Macroeconomic Policy Frameworks for Resource-rich Developing Countries"(2012) <www.imf.org > accessed 16 January 2016.

International Monetary Fund (IMF). "Fiscal Regimes for Extractive Industries: Design and Implementation" (2012) < www.imf.org > accessed 16 January 2016.

Jonsson, J and Byceson, D. "Rushing for Gold: Mobility and Small-Scale Mining in East Africa", Development and Change (2009), No. 2, Vol. 40, 247-279.

Kaufmann, D. "Poverty in the Midst of Abundance: Governance Matters for Overcoming the Resource Curse" (The Brookings Institute, 2012) < http:/ /www.brookings.edu/research/opinions/2012/09/13-poverty-governancekaufmann > accessed 16 January 2016.

Le Billon, P. "Extractive Sectors and Illicit Financial Flows: What Role for Revenue Governanace Initiatives?” (Chr. Michelsen Institute, Bergen: Norway 2011), Working Paper, No. 13.

Lopes, C. "Leveraging Africa's Extractive Sector for Inclusive Economic Transformation" (GREAT Insights, 2014), No. 7, Vol. 3.

Mbayi, L. "Linkages in Botwana's Diamond Cutting and Polishing industry", (University of Cape Town, No. 6, 2011)MMCP Discussion Paper.

Mckinsey Global Institute. Lions on the Move: The Progress and Potential of African Economies (2010). 
Mckinsey Global Institute. Reversing the Curse: Maximising the Potential of Resource-Driven Economies (2013).

Morris, M., Kasplinsky, R. and Kaplan, D. One Thing Leads to - Commodities, Linkages and Industrial Development: A Conceptual Overview (The Open University, Milton Keynes, UK, 2011).

Ncube, M. "African Mining - Opportunities and Challenges: How We Made It in Africa", Journal of Africa Economic Brief (AfDB, 2012a), No. 6, Vol. 3, $<$ www.afdb.org > accessed 16 January 2016.

Ncube, M. "Mining Industry Prospects in Africa" mimeo, Journal of Africa Economic Brief (AfDB, 2012b), No. 6, Vol. 3. <www.afdb.org > accessed 16 January 2016.

OECD. OECD Transfer Pricing Guidelines for Multinational Enterprises and Tax Administrations (OECD, Paris, 2010).

OECD Development Centre. Second Meeting of the Policy Dialogue on Natural Resource-based Development, Summary Report (OECD, Paris, 2014).

Oyejide, A. and Adewuyi, A. "Enhancing Linkages of Oil and Gas Industry in the Nigerian Economy" (University of Cape Town, 2011) MMCP Discussion Paper, No. 8.

Pedro, A. "The African Mining Vision: Towards Shared Benefits and Economic Transformation", GREAT Insights, 2012) No. 5, Vol. 1.

Pritchard, W. "The Minerals Boom in Sub-Saharan Africa: Continuity, Change and Prospects for Development", in H. Melber and R. Southall (eds) The New Scramble for Africa? Imperialism, Investment and Development (Durban, KwaZula-Natal Press, 2009).

Roberts, C. "The Other Resource Curse: Extractives as Development Panacea" (Cambridge Review of International Affairs, 2015), No. 2, Vol. 28, <http:/ /afraf.oxfordjournals.org/content/114/457/672.extract> accessed 16 January 2016.

Ross, M. The Oil Curse: How Petroleum Wealth shapes the Development of Nations (Princeton University Press, Princeton, NJ, 2012).

Tedom, F. and Noah, Noh F. "The Role of Regional Cooperation in the Context of West African Oil" (GREATS Insights, 2014), No. 6, Vol. 3.

Stevens, P., Lahn, G. and Kooroshy, J. The Resource Curse Revisited" (Chatham House, London, 2015).

Transparency International and Revenue. "PromotingRevenue Transparency Report on Oil and Gas Companies" (2011) < http://www.transparency. org $>$ accessed 16 January 2016.

United Nations Conference on Trade and Development (UNCTAD). Fostering Industrial Development in Africa in the New Global Environment. Economic Development in Africa Report(UNCTAD, NY and Geneva, 2011).

UNCTAD. World Investment Report (UNCTAD, Geneva, 2013).

United Nations Economic Commission for Africa (UNECA). "Africa Governance ReportNo 2 (UNECA, Addis Ababa, 2009).

UNECA. Minerals and Africa's Development: The International Study Group Report (UNECA, Addis Ababa, 2011). 
UNECA. Mineral Resources for Africa's Development, Issues Paper, African Development Forum (UNECA, Addis Ababa, 2012).

UNECA. Making the Most of Africa's Commodities: Industrialization for Growth, Jobs and Economic Transformation (UNECA, Addis Ababa, 2013).

UNECA. Illicit Financial Flows: Report on the High-level Panel on the Illicit Financial Flows from Africa (UNECA, Addis Ababa, 2015).

United Nations Economic and Social Council (ECOSOC). Africa Review Report on Mining (ECOSOC, New York and Addis Ababa: UN, 2009).

US Government. Dodd-Frank Wall Street Reform and Consumer Protection Act (US Congress, Washington DC, 2010).

Wanzala, M. and Groot, R. "Fertilizer Market Development in Sub-Saharan Africa". International Fertilizer Society Conference Proceedings (Windsor, International Fertilizer Society, 2013).

World Bank. The Power of the Mine: A Transformative Opportunity for subSaharan Africa (World Bank Washington DC, 2015).

World Bank. Increasing Local Procurement by the Mining Industry in West Africa (World Bank Washington DC, 2012).

World Bank 1992. Strategy for African Mining (World Bank Washington DC, 1992). 